\title{
Culture, power, and identity The case of Ang Hien Hoo, Malang
}

\author{
MELANI BUDIANTA
}

\begin{abstract}
This paper discusses the intricate relations between culture and identity in a web of larger power structures of politics and the market by looking at the ways in which the Indonesian Chinese attach themselves to a local performing arts tradition. The paper focuses on the history of the wayang orang amateur club called Ang Hien Hoo in Malang, East Java, which emerged from a Chinese diaspora burial association, to attract national limelight in the 1950s and 1960s. In this paper, I see this amateur club as a site, not only for cultural assimilation, but also as a meeting space for the diverse migrant Chinese population residing at a host country. The space is used to negotiate their position as citizens responsible to promote and to become patrons of local traditional performing arts. The paper examines how this amateur club was swept by the Cold War politics and national political turmoil of 1965, and how it fought to survive under the pressures of the global capitalist era. What emerges from the findings is the contradictory fact that the identification of the Chinese with the Javanese traditional performing arts is affirmed precisely as it is marked by Chineseness. Thus, despite the cultural blending, the Chinese Indonesian's patronage of local traditional art continuously reproduces the double bind of making home in the culture not seen as their own.

KeYWORDS

Chinese Indonesian; wayang orang; politics; cultural identity; patronage of local performing arts.
\end{abstract}

MELANI BUDIANTA, Professor of literary studies, Faculty of Humanities, Universitas Indonesia, has done researches on issues of cultural diversity, transnational cultural flow, diaspora, gender, and postcolonial studies. Her recent publications include Indonesian women writers (Berlin: Regiospectra, 2015) as co-editor with Yvonne Michalik; "Precarious cosmopolitanism; Work migration and cultural belonging in globalized Asia", International Journal of Cultural Studies Vol. 19/3 (2016): 271-286; and "Malang cosmopolitanisms of the 1960s", in: Sharmani Patricia Gabriel and Fernando Rosa (eds), Cosmopolitan Asia; Littoral epistemologies of the Global South, pp. 82-104 (London: Routledge, 2016). Melani Budianta can be contacted at: melani.budianta@ gmail.com.

(C) 2017 Faculty of Humanities, Universitas Indonesia

MELANI BUDIANTA | DOI: 10.17510/wacana.v18i2.593. 


\section{INTRODUCTION $^{1}$}

In one of the city festivals in Malang, East Java, in 2006 the Javanese wayang orang $^{2}$ theatre organized by a Chinese burial association Ang Hien Hoo (called Panca Budhi since mid-1960s) - played one of the most dramatic scenes in an episode called "Birth of Setyaki", the little protagonist Prince Setyaki was about to be devoured by a tiger. Instead of a tiger, however, a Chinese barongsay (lion dance) player from the En Ang Kiong temple - stepped into the scene. The audience cheered.

The ex-director of the burial association, a dentist and an army colonel Ong Tjong Bing, remembered the scene as one of the new experiments to revive the wayang orang legacy bequeathed from the older generation of Chinese players for today's audience. As he reminisced of the paths the association had gone through, Ong Tjong Bing reflected on the internal turmoil as well as the external challenges, through which the organization had to undergo in order to survive. ${ }^{3}$

The case I am presenting in this paper, about a burial association founded in 1914 by the name of Ang Hien Hoo in Malang, with its originally all-Chinese Wayang Orang Group famous in the 1950s and its present legacy, is not a case of a mere "multicultural" or "hybrid" mix-match between a Javanese and Chinese performing arts tradition. Instead, the wayang and lion dance encounter in the "Birth of Setyaki" signify the complicated process by which Chinese Indonesians negotiated with historical forces - political, economical, and cultural - in constructing their identities through the arena of arts and culture.

The spread of Chinese voluntary organizations amongst Chinese diaspora has been discussed by Pearce (2005), and the way Chinese migrants engage in performing arts in host countries have been examined from its cross-cultural

1 This article is a revised version of a paper presented at the International Conference "Issues and Trends in Southeast Asian Studies", held at the University of Michigan, 22 October 2010. I am indebted to Abdul Malik who gathered ex Ang Hien Hoo players for a public discussion on 4 November 2016 and for providing contacts for subsequent interviews in Surabaya and Jakarta.

2 Wayang means shadow, and the first wayang art in Java used shadow puppet. The wayang orang is a form of traditional theatre, by which human dancers imitate the movement of the shadow puppet. The story is usually based on the Mahabharata, and sometimes Ramayana. One full play could last for three to four hours, staging one particular part of the Mahabharata story, with many variations. A shorter version of the play, staging a new story based on the Mahabharata or Ramayana characters (often adding new ones), is called carangan. The wayang orang play is delivered in archaic Javanese dialogue, most of it sung in a melodious chant. The characters of the refined male heroes (bambangan) are played by women, while the masculine ones and the antagonists are played by male dancers. In the middle of the play is a comic relief scene - comparable to that in the Shakespearean tradition - which is much awaited by the audience. Here the hero's servants called punakawan perform slapstick comedy and satirical humor on social political commentaries relating to contextual issues. Originally, the wayang theatre was performed in the palaces of the Javanese kings in Surakarta and Yogyakarta, but eventually the theatre became popular entertainment, especially in Central and East Java. See Soedarsono (1984 Wayang wong. Yogyakarta: Gadjah Mada University Press).

3 Interview with Ong Tjong Bing, Malang, 14 July 2010. 
dimension (Um 2005). My paper relates to the ongoing discussion about the space created by burial association as a voluntary organization in creating this engagement with local and not Chinese performing arts. As the socio-cultural dimension of the Chinese diaspora in Indonesia is much intertwined with political forces, a great proportion of the paper is spent in situating the cultural praxis within the historical context. ${ }^{4}$ Although the discussion of globalization and the marketplace is not central in the paper, the case study of the amateur performing art in Indonesia begs the question of how this out-of-the market position should be theorized.

The paper starts by comparing three historical documents, the Ang Hien Hoo anniversary books of the 1935, 1940, and 1960, to map the journey of Ang Hien Hoo since its inception in 1910 as a Chinese burial association to an Indonesian foundation which promotes social welfare and traditional performing arts. ${ }^{5}$ The second part of the paper looks at the way in which the organization strategized to cope with the changing political regimes, and the way in which the association and the Wayang Orang Section have to deal with the new cultural politics. Mapping the continuity as well as disruption in the history of the organization, the paper argues that the burial association and its various cultural sections serve as a civic space for the diverse population of Chinese living in Malang from the early twentieth century to the present to negotiate their positions as citizens as well as to deal with their internal cultural differences in the face of the changing times. The third section discusses the internalization of Javanese culture within the Chinese community, creating a sense of belonging. By attaching themselves to local performing arts tradition, the Chinese position themselves culturally in a non-essentializing way as patrons of local traditional arts, negotiating with the larger power structures of politics and the marketplace.

\section{HONG BOEN ASSOCIATIONS AS A CIVIC SPACE FOR A HETEROGENEOUS POPULATION}

William (1960: 110), in her classical work on the Pan-Chinese nationalism in Indonesia from 1900-1916, considered burial associations as one of the earliest institutions founded for gathering Chinese settlers in various places of their migration. This is true in Malang, East Java, where waves of Chinese migrants made their home, coming directly from mainland China or from other previous places of settlements in the Indonesian islands.

The Chinese in Malang originated mostly from Southern China, with Hokkien as the dominant group, the Teo Chew and Cantonese in smaller

4 For a larger picture of the Southeast Asian diaspora see Michael W. Charney, Brenda S.A. Yeoh, and Tong Chee Kiong (2003, Chinese migrants abroad; Cultural, educational, and social dimensions of the Chinese diaspora).

5 The role of the Chinese as the earliest patrons of the wayang orang theatre outside the Javanese court was noted by James R. Brandon (2009: 47), identifying a Chinese businessman by the name of Gan Kam, who "established the first professional troupe in Surakarta", a fact mentioned also by Go Tik Swan (Rustopo 2008: 9). The Chinese, in this aspect, turned a court art into a popular, money making art form. The Malang Chinese' patronage of the wayang orang art, in contrast, is not characterized by this entrepreneurial character. 
numbers. Each ethnic group spoke in their own dialects and had their own clubhouses. They settled through different waves of migration. There was no clear record of the earliest settlement in East Java, although archaeological remnants of Chinese ceramics in the area dated as early as tenth and eleventh century. In the early nineteenth century, the Chinese settlers in Malang must have reached a significant population, for by 1825 they had built a Chinese temple named En An Kiong as a place of worship as well as a community centre (See Figure 1).

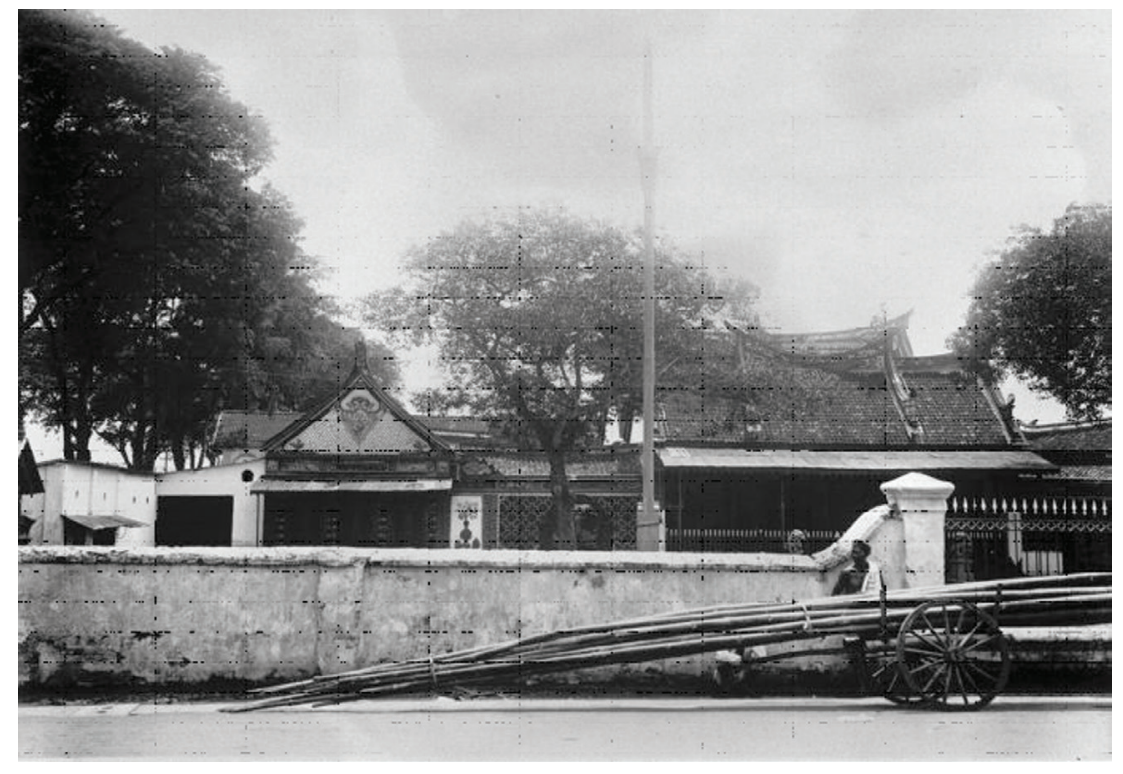

Figure 1. En An Kiong Temple (1825-present) at the Chinatown area in Malang (Collectie Tropen Museum Nr. 60005938).

Before 1920s, most of the Chinese lived in the Chinatown in one of the oldest, southeast area of the city, but as the city expanded based on class (socioeconomic) mapping, the Chinese spread to all parts of the city. In 1950s, after the Dutch vacated the city, the rich Chinese occupied the elite residential area in Malang, originally owned by the Dutch. The Chinese were also divided by their education. In 1905 the Chinese opened the Malang branch of Tiong Hwa Hwee Kwan Chinese School. In 1909, the Dutch founded the HCS (Hollandsch Chineesche School, the Dutch Chinese School). With the growth of Catholic schools, many younger Chinese generation were brought up in the Dutch educational system. ${ }^{6}$

The growing number of the Chinese population in the city, with their diverse backgrounds, different schools, and residential areas, had one similar

6 Most Chinese settlers in Malang by 1930s had moved out of the Chinatown area to settle down to a different area of the city, which was designed by Dutch architect John Karsten based on the socio-economic division (Handinoto 1996). See the description of the city development in Van Schaick (1996). 
need, explicitly, a social organization to help them with the dead and burial. The burial association, named Ang Hien Hoo, was established in 1910 for that matter, in close association with and close proximity to the En An Kiong Temple.

In this section I examine the expanding role of Ang Hien Hoo, from a social space to accommodating cultural diversity of the Chinese to be the patron of the local traditional arts. My data derive mostly from the three Ang Hien Hoo anniversary books: the 25th (in 1935, see Figure 2), the 30th (in 1940), and the 50th (in 1960). The anniversary books were published by a special committee, which in the first two books invited contributors, not only from its own members, but also from members of other "sister organizations" (zustervereniging) from all over Java. The anniversary books described the event of the celebration, and most importantly the history of Ang Hien Hoo and the network of Hong Boen organizations in Java.

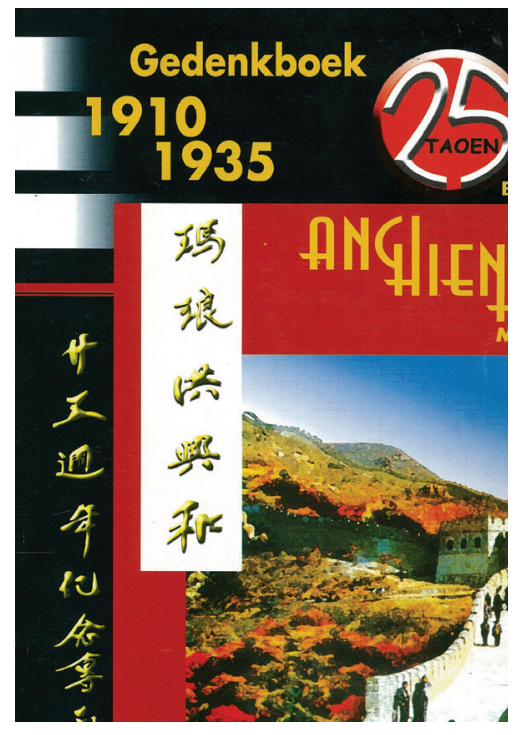

Figure 2. The Ang Hien Hoo 25th anniversary book reprinted in 2006 (Courtesy of the En Ang Kiong Temple Foundation, Malang).

It was apparent from the three books that at the turn of twentieth century Hong Boen or burial associations in Java served as social centres to organize not only burial needs, but also economic, social, and cultural affairs of the growing Chinese migrants in the cities in Java. By 1930s burial associations had spread in big cities in Java (Batavia, Bandung, Surabaya, Pasuruan, Jember, Semarang, Jember, Solo, Yogyakarta, Pemalang, Madiun), necessitating a need to form a federation.

The Hong Boen organization examined in this paper, Ang Hien Hoo (or the Panca Budhi association), was formally registered in 1910 (with an initial informal group called Tian Tee Hwee set up as early as 1903) on the Kwietang Street (or latter called Pertukangan Street) in the Chinatown area in Malang. In the 25th anniversary book of the organization published in 1935, one reason highlighted for the founding of the association was to unite a growingly dispersed Chinese diaspora in the city. One major division mentioned was 
the gap between the newly migrant Chinese who adhered to the language and culture of the originating homeland (called totok), and the migrants who had settled down from generations, intermarried and culturally assimilated to local cultures, known as the Peranakan: ${ }^{7}$

The harmony of the people is fragmented here and there; many groups of different ethnicities work for the interest of their own groups, and at the same time the totok and Peranakan Chinese are like water and oil, so it is the responsibility that our leaders have fortunately taken up to find a "uniting bond" to secure the harmony of our people, who have been so dispersed. ${ }^{8}$

The importance of uniting the Chinese was emphasized again in the 30th anniversary book, this time referring to the dichotomy of "the conservative" (kaoem kolot) and "the modern" (kaum modern):

It is a pity that today there is this unfortunate condition that the conservative and modern do not want to work hand in hand. In fact, the conservative is so hard minded, refusing to listen, while the modern do not care less and tend to ignore them. ${ }^{9}$

The writers of the 1935 anniversary book cited "democratic principle" as the basis for forming the association, as it tried to be inclusive of the rich and the poor, as well as the totok and Peranakan.

The principle of democracy was taken up as the basis of the foundation of Ang Hin Hoo, whereby the association opens its door for all Chinese, without considering their background, whether they are poor or rich, totok or Peranakan, as long as they behave well, they can be a member. ${ }^{10}$

From the essays collected in the three anniversary books published from

7 The two terms, totok and Peranakan, were a sociological construct used widely for ingroup and out-group identification amongst the Chinese communities before the New Order assimilation policy of the Chinese in 1965. By the 1998, when the New Order collapsed, the two terms were no longer relevant as all Chinese had adopted Indonesian as their language. However, the trace of the divide still resonated today in some degrees. See further discussion of these two terms in its historical context (Twang 1997) as well as its (ir)relevance in the twentyfirst century Indonesia (Hoon Chang Yau 2008).

8 "keroekoenannja bangsa terpentjar disana sini; banjak golongan jang terdiri dari satoe bangsa saling hidoep boeat kepentinganja sendiri, dan berbareng itu antara kalangan Tionghoa totok dan pranakan hidoepnja sebagi aer dan minjak, maka ada menjadi satoe kwadjiban jang soekoerlah boeat pemimpin kita di itoe masa bisa dapatken 'tali persatoean' boeat mengikat pada keroekoenannja bangsa kita jang soeda terpentjar" (Tjoe Sing, L. Suma et al.1935: 1, my translation).

9 "Sayang ini waktoe masih ada katjiwa, jaitoe antara kaoem kolot dan modern satoe sama lain masih belon maoe bergandengan tangan, malah sikolot tinggal koekoeh serta tida mau mengindahken, dan simodern tida maoe perdoeli serta soeka memblakangken" (Liem Thiam Kwie, Ong Tjing Poen, and Kwee Liang Djie 1940: 64, my translation).

10 "Krana lahirnja Ang Hin Hoo ada mengambil dasar 'democratie' dimana itoe perkoempoelan memboeka pintoenja boeat berbagi-bagi golongan TIonghoa zonder pandeng soeal kaja dan miskin, totok dan pranakan asal berklakoean baek bisa ditrima mendjadi anggotanja" (Tjoe Sing, L. Suma et al. 1935: 1, my translation). 
1935 to the1960, we can imagine that such effort in unifying the "dispersed" Chinese must have been challenging. The Chinese were not only separated by their cultural upbringing (totok or Peranakan), but also by language (Dutch, Malay, Chinese languages), education (Dutch or Chinese schools), their class and residential area, and religion (many adopted Christianity). ${ }^{11}$

The heterogeneity of the Chinese population could be seen from their cultural expression, the rich and diverse cultural references (Chinese, Dutch, Malay, Javanese) and variety of their choice of arts, which could be traced from the three anniversary books of 1935, 1940, and 1960. It is important to note that Ang Hien Hoo as a Hong Boen association has been from the start very closely located and related to the En Ang Kong Temple. They shared many resources together, including personnel for running various programs. The closeness to the temple and the nature of Ang Hien Hoo as a burial association underlines the centrality of Chinese customs and rituals. The 25th anniversary ceremony, for example, began by a parade of carrying the statues of the Five Elders from the En Ang Kiong Temple, followed by the lion dance troupe through the Chinatown streets to the office of Ang Hien Hoo to be reinstalled for prayers. ${ }^{12}$

The legend of the Five Shaolin Elders (called Ngo-Chow in Hokkien), whose statues were always put in a special altar in the Ang Hien Hoo offices, was a foundational narrative, which has been passed on from one generation to another up to the present. The anniversary books traced the origin of Hong Boen associations to the persecution of Shaolin Temple priests during the Qing dynasty in the eighteenth-century China. The five elders who survived the burning of the temple and persecution were considered to be the founding fathers of the secret societies under the guise of burial association, spreading not only in China but also in Southeast Asia. The history of the five elders was presented as an expression of people's resistance against the reign of the Manchus, and connected to the overthrow of the Qing dynasty and the birth of nationalist movement by the founding father Sun Yat Sen. Closely associated with the legend of the five elders, Chinese martial arts (called kunthao) were centrepiece in the celebration of the 1935 and 1940 anniversary events. Besides the lion dance troupes, Ang Hien Hoo celebrations included Chinese music Yangkhiem band (Chinese traditional music) and for the first two anniversary events, Chinese choir of the Malang Chinese Boy Scouts organization (Hua Chiao Tsing Nien Hui, abbreviated as HCTNH).

11 After 1945 there was further political and ideological division between those who were pro Taiwan or pro PRC. After Indonesian independence, the division was based on those who chose to be Indonesian citizens, PRC citizens, and those who became stateless due to their choice of supporting the Taiwanese government (which was not acknowledged by Indonesia) or their inability to procure documents in order to register as Indonesian citizens. In the 1960s Chinese Indonesians were split in their differing cultural strategy in establishing their cultural identity, either through cultural assimilation or political integration of citizens with Chinese cultural identity.

12 See Buku kenang-kenangan kirab ritual dan budaya peringatan HUT kelenteng Eng An KiongMalang ke 182 (1825-2007) (2558 Ni Lak Gwee Ce Lak - 19 Juli 2007) (Malang: Wika En An Kiong. 2007). 
Although discussion about Chinese philosophy, and the importance of "Eastern spirit with authentic Chinese essence" (soemangat katimoeran mendekatin ketoelenan Tionghoa) was reiterated in the collected articles of the anniversary books of the 1935 and 1940, the themes were expressed in Malay, replete in Dutch vocabulary and idioms, quoting references from English literature and philosophy. An example from a quote below betrayed the Dutch educated milieu of the contributing writer, in contradiction with his denunciation of Western influence (Dutch and English words put in bold):

Kaloe bangsa itu berwatek slaafsch (memboedak) tentoelah kunst akan bersifat slaafsch djoega, baek slaafsch dalam arti tjoema meniroe (copyeeren) atawa verstard (teriket), jaoitoe tida berani mengadakan perobahan baroe, kerna terprentah oleh sleur (aliran kebiasaan). Maka itoe, perloe sekali kita, bangsa Tionghoa, djangan selaloe meniroe sadja pada kunst Barat (diprentah oleh cultuur Barat), hingga kahilangan garis hidoep dan menjadi speel bal (bal-balan) dari grillen van het oogenblik (mode), aken tetapi kita haroes menanam benih cultuur kita sendiri, agar kita bisa membangoenken hidoep baroe boeat teroesannja hidoep kita jang soeda lalu, lantaran apa di Tiongkok sekarang moentjoel gerakan jang dinamaken "New Life" bersandar sebagian atas peladjaran dari Khongtjoe.

Bangsa Timoer jang tinggi kasopanannja telah tjaplok "beschaving" Barat, met huid en haar (ditelen boelat-boelat), boektinya siotjia-siotjia kita soeda pande "dansa" memperliatken pahanja depan oemoem, sifat atawa kesoekaan mana, soeda terang bertentangan dengan kita poenja kodrat. Tida salah kaloe Twain bilang

\section{West is West, and East is east, The Twain'll never meet.}

Barat ada barat, timoer ada timoer,

Doea-doea tida bisa bertjampoer. (Lio Lo Tjia in Tjoe Sing, L. Suma et al. 1935: 34.)

This quote is a telling example of first of all the influence of the Western/Dutch educated milieu in the Chinese diaspora in Java. The writer reprimanded the East for "swallowing" Western influence, while at the same time inscribed the West in the very text itself. The quote also gives us the context of the leisure activities of the Dutch educated elite in urban centres of East Java, including Malang. Ball room dancing and musical band were favourite pastime amongst the "modern" Chinese youth. The writer above was eager to distance the Ang Hien Hoo from the modern "fad" amongst the growing population of students in Malang. In the 1930s, Malang had grown to be an educational centre, a favourite place for Chinese parents from neighbouring cities to send their children to the growing number of boarding schools developed by the Catholic orders. Then there were already 50 primary to secondary schools, including the Chinese, the Dutch Chinese schools and a variety of other schools, including Catholic and Islamic schools, Montessori and Muhammadiyah schools. The essays in the 1935 and 1940 anniversary books also suggest that there was a pool of highly educated intellectuals. Besides a reference to Mark Twain, there was a discussion of Rudolph Steiner's system of education, and a comparison 
between Chinese Hong Boen and English freemasonry, citing a reference in English.

Another strong cultural orientation shown in the three anniversary books is the grounding of the Hong Boen in Malay culture and language. Apart from a few opening pages in Chinese characters in the first two anniversary books (1935 and 1940), the rest of the books were written in Malay. It can be assumed that most of the speeches were delivered in Malay, as the report of the 25th anniversary mentioned explicitly when some speeches were delivered in Mandarin: "A statement of Dr. Sun [Yat Sen] was read in Kuo $Y u$ [Mandarin]" (Tjoe Sing, L. Suma et al. 1935: 4). ${ }^{13}$ The fact that there was a new generation of Malay speaking Chinese in 1935 could be detected from the way in which many writers in the 25th anniversary books addressed "those who read in Malay":

If so far the name of "Ang Sioe Tjwan" is alien in the Malay readership, this is not surprising, because books written in Malay rarely published about the biography of "Ang Sioe Tjwan" (Han Kang Hoen in Tjoe Sing, L. Suma et al. 1935: 36). ${ }^{14}$

A number of authors from the 1935 and the 1940 anniversary books, like Han Kang Hoen quoted above, served as a bilingual cultural translator, passing on stories of Chinese leaders, legends, and philosophies, quoting passages from Chinese texts (in Latin), then translated it into Malay.

The articles collected in the anniversary books also showed the extent to which the Chinese society in Java was grounded in local context. Writers were keen in following political movement of other groups. One writer compared Ang Hien Hoo with the Syarikat Islam (Tjoe Sing, L. Suma et al.1935: 19). ${ }^{15}$ Another urged the organization to be as successful as another organization called IEV (Indo Europeesch Verbond, Indo European Alliance). References to Mahabarata story or characters suggest familiarity with the Javanese wayang orang or wayang kulit tradition, which popularized the stories for the wider public. One example is the comparison of treacherous and unreliable political elites amongst the Chinese in Indonesia to "Dorna", the consultant of the Kurawa family who devises various sly strategies for defeating the Pandawa family (Tjoe Sing, L. Suma et al. 1935).

It was not only the Peranakan or culturally assimilated Chinese that embraced the local language and culture. The newly migrated Chinese traders who resided in the Chinatown area were fluent in East Javanese colloquial language as a means for communicating with their costumers and as a lingua

\footnotetext{
13 "dibatjahken testament Dr. Sun dalam bahasa Kuoyu".

14 "Laloe sampe sebegitoe djaoe itoe nama 'Ang Sioe Tjwan' masih terasing dikalangan pembatjahan melajoe, ini poen tida moesti diboeat heran, oleh kerna boekoe-boekoe jang tertjitak dalem bahasa melajoe; djarang sekali menjitak tentang riwajat pengidoepannja 'Ang Sioe Tjwan'"' (Han Kang Hoen in Tjoe Sing, L. Suma et al. 1935: 36).

15 "Kaloe tida kliroe, perkoempoelan Ang Hin Hoo didiriken ampir bebarengan dengen lahirnya perkoempoelan 'Sarekat Islam' yang terpimpin oleh Almarhoem toean HOS Tjokroaminoto" (Sie Tjoe Tik in Tjoe Sing, L. Suma et al. 1935: 19, my translation).
} 
franca to communicate with the Indians, Arabs residing in the market centre area. The En Ang Kiong Temple in Malang was always known to have one of the oldest gamelan set. The po-te-hi or the Chinese puppet shows, performed during Chinese festivals in the temple, were delivered in mixed languages of Hokkien and the colloquial East Javanese dialect.

It is not surprising, therefore, to discover that the gamelan was a part of the Ang Hien Hoo anniversary celebration. In 1935, the gamelan music was not in the centre of the celebration, but was played as background music even from the day before the anniversary party:

One day before the Jubilee night a number of members and administrative staff were sitting enjoying themselves while listening to the gamelan orchestra, which was contributed by Mr Liem Hok Tjien, one of the members of Ang Hien Hoo, Malang. ${ }^{16}$

The quote above also explains the unstructured yet grounded connection between the function of Ang Hien Hoo as a burial association and its expanding role as the patron of arts and culture. Hong Boen association was considered central in Chinese diaspora society as suggested by the title of the essay written by a well-known Malang journalist, Pouw Kioe An, for the 30th anniversary book "Hidoep boeat mati?" (To live in order to die?) (Pouw Kioe An in Liem Thiam Kwie, Ong Tjing Poen, and Kwee Liang Dji 1940: 54-55). First of all, the "proper" ritual and respect to the dead is important for the Chinese, but as Pouw Kioe An and the earlier quotes suggested, the organization was intended to be a meeting place for Chinese citizens to discuss their social and economic welfare. As a social organization, Ang Hien Hoo served as a meeting place and was soon filled with a variety of arts and cultural expressions of its members. Special divisions could be formed to accommodate the members' interest in sports or in music, or dance. As the membership fee was intended for burial services, additional costs of these sports and cultural division were usually borne by the participants. These additional divisions were thus functioning like amateur clubs. During anniversary celebrations, musical or arts performance by these different sections were considered as personal or group "contribution". Members of Ang Hien Hoo were also active in other organizations, and they would mobilize support from other organizations, such as the Chinese Boy Scouts $(\mathrm{HCNTH})$, which always participated to guard the parade and to contribute their Chinese choirs. These hobby clubs did not function merely as a hobby club, but as a "social" means of fundraising activities for Ang Hien Hoo. In this way, the organization could give charity funds during natural disasters and perform its role as social organization for the wider public.

The sports, arts, and cultural division of Ang Hien Hoo, thus expanded, narrowed down or shifted according to the members' interest. In 1935, one

16 "Satoe hari dimoeka maleman Jubileum bebrapa leden dan bestuurs sama berdoedoek seneng-seneng sambil dengerin satoe gamelan soembangan dari soedara Liem Hok Tjien, lid Ang Hien Hoo - Malang" (Tjoe Sing, L. Suma et al. 1935: 3, my translation) 
member contributed the performance of a gamelan orchestra, which did not appear in the 1940 celebration. From 1935 to 1940, the drama (Dutch toneel) division of Ang Hien Hoo was formed and staged performance in Surabaya ${ }^{17}$ During this period, members were keen in organizing "excursion" trips to Madura, Dieng plateau, the Gambir Bazaar, and night festivals to commemorate the 200th anniversary of Surakarta.

The 1950s-1960s witnessed the expansion of Ang Hien Hoo's division to include chess, badminton and billiard pools, gamelan (and wayang orang), Yangkhiem/Pat Iem and choir. The Wayang Orang Division, which was started in the 1950s, attracted large membership from diverse background, from elite businessmen and their families to shop attendants and workers. The fascination for this Javanese art was attributed by its members as nostalgia for an art which was close to their childhood upbringing. There were various waves of migration of Chinese from the neighbouring villages and cities in East Java to Malang during the Japanese occupation and during the Dutch military aggression in 1947, and in 1959, when foreign nationals of Chinese background were not allowed to do business in the rural area. They remembered their exposure to gamelan and wayang orang in their childhood in the villages, and were keen in expressing themselves in this art. Malang was in the 1950s home for cigarette companies and tobacco merchandise, and a number of Chinese merchants, who were ardent lovers of the art, served as loyal sponsors of Ang Hien Hoo. One tobacco merchant used the badminton yard in the back of his home as a place to recruit young Chinese children, hired teachers to train them and to select the best for casting in Ang Hien Hoo. ${ }^{18}$ The Javanese dance and wayang orang theatre instructor was hired from Yogyakarta, and participants practiced regularly in the auditorium of Ang Hien Hoo. Ex-members interviewed today remembered the difficulty in memorizing archaic Javanese language and songs in the dialogues. ${ }^{19}$ As it performed for various fundraising activities and festivals in other cities in Java, this all-Chinese gamelan (Figure 3 ) and wayang orang theatre group became well-known nationally, and the name Ang Hien Hoo was better known for its wayang orang group than for its burial association.

In the 50th celebration of Ang Hien Hoo in 1960, the gamelan, which was in the periphery in the 1930 celebration, and the Javanese wayang orang theatre now occupied the centre of attention. Right after the speeches, two opening numbers were given to a wayang orang tableau and the enactment of a short scene. The 1960 anniversary book also mentioned the success of Ang Hien Hoo in the wayang orang performance held at the State Palace in Jakarta, and in many other places for fundraising activities for victims of accidents,

17 What was mentioned in the 1940 book was the theatre activities of the Ang Hien Hoo group, performing for sister organization in Surabaya. The title is in Chinese "Ong Oen Hwan Lian Kee".

18 The name of the tobacco merchant was Go Hok Gian. He trained his two daughters, and in particular his eldest daughter, Go Han Iem, to be the one lead players in Ang Hien Hoo in the mid-1960s.

19 Sari Endahwarni, Jakarta, 10-7-2010, interview; Ermawati, telephone interview, 9-7-2010. 
building schools, and "gifts for the war fronts". A special praise is directed to the Wayang Orang Division, which "recently has progressed in such a way that give a good name not only to the Ang Hien Hoo association, but also the name of the Indonesian citizens from Chinese descent in Indonesia". ${ }^{20}$ The 50th anniversary celebration, for example, still presented the Jangkhiem music as in the previous celebrations, but instead of Chinese martial arts and Chinese choir, there were the Sumatran Serampang 12 dance and comedy in East Javanese and Malay (dagelan).

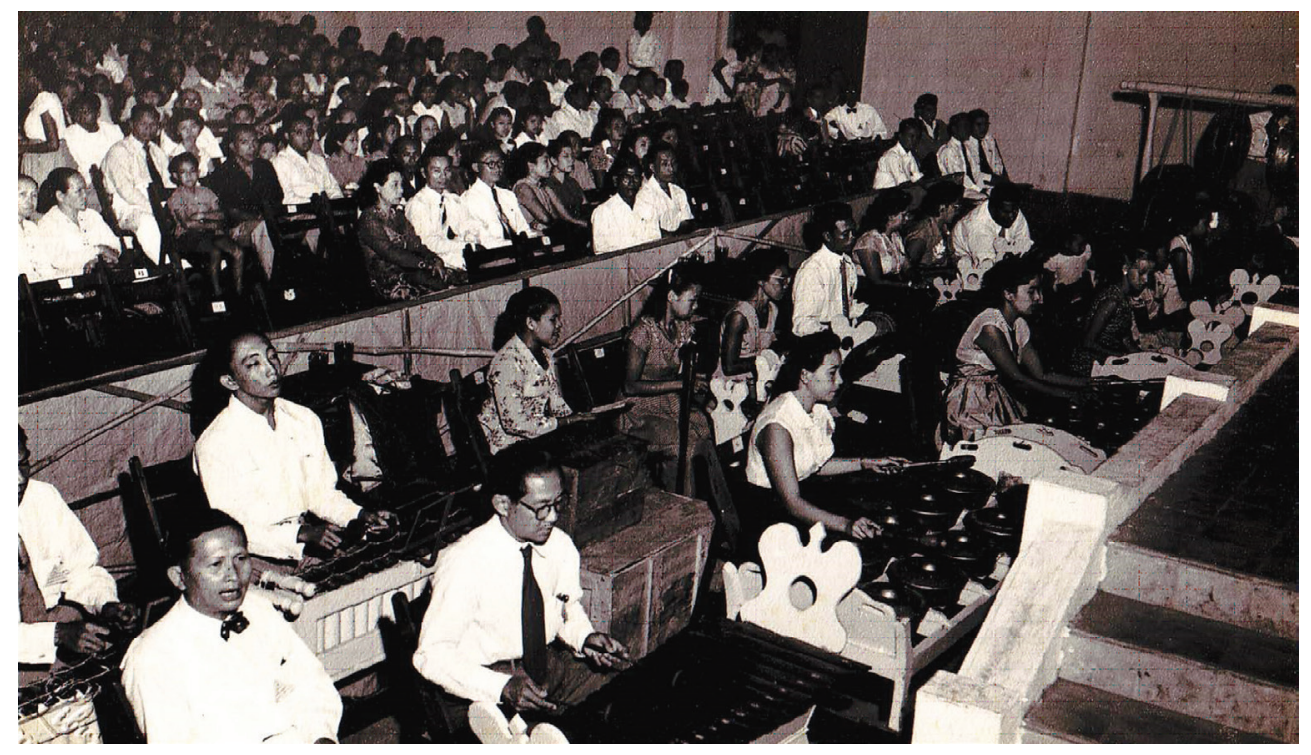

Figure 3. The Gamelan and Karawitan Orchestra of Ang Hien Hoo in the 1950s (photographed by Ong Kian Bie, courtesy of Ong Ay Ling).

The three anniversary books give evidence of the plurality of cultural references and choices of arts and leisure activities amongst the Chinese in Malang, East Java. As a social organization that adopted the principle of democracy and inclusiveness (amongst the Chinese), Ang Hien Hoo had shown attempt to embrace the cultural diversity of its members, and to be open to the views of the sister organizations from all over Java. The close proximity between the Ang Hien Hoo burial association to the Chinese En Ang Kiong temple guarantees the continuous link with the Chinese arts, ritual and customs. However, as shown in the 1960 anniversary book, Ang Hien Hoo as a burial association had expanded to play a role as patron of the national (read Indonesian) arts and culture.

20 "Bagian seni Wayang Orang, ternyata di hari-hari jang terachir ini, telah memperoleh kemadjuan begitu rupa, sehingga mengharumkan bukan sadja nama perkumpulan Ang Hien Hoo, djuga pun nama Warga Negara Indonesia keturunan Tionghoa di Indonesia" (Tan Ping Tjiat in Tjan Tan Soen 1960: 12). 


\section{NAVIGATING THE CURRENTS OF POLITICAL FORCES AND CULTURAL POLITICS}

The nationalistic development of Ang Hie Hoo was necessitated by the changing political currents of the time. This section discusses the way Ang Hien Hoo navigated along the currents of political forces and different regimes of cultural politics. When Ang Hien Hoo celebrated its 25 th and 30 th anniversaries in 1935 and 1940, the Chinese in Malang were both citizens of the Dutch Indies and members of the Chinese diaspora, who kept themselves abreast about any social and political changes in the mainland China. The organization aimed at both giving support to the social causes in the mainland China as well as in the country they were residing:

The reasons behind the Chinese organizations are to advance the cause of our people and country: 1) to support Khik Bing, Pakhwatkoen, the war in Shanghay, the flood, famine and other needs of our people; 2) other needs that we have here, to help the poor, the jobless and our representatives in the parliaments. ${ }^{21}$

It was to be expected that they started the 25th and 30th anniversary parties by singing the "national anthem" Tien Hsia Wei Kung ${ }^{22}$ and reading Dr Sun Yat Sen's statement in Mandarin. On the 30th anniversary, besides the singing of the national anthem, the audience paid homage to the "Tangkuochi" or national flag, and to the pictures of Chiang Kei Sek, Dr Sun Yat Sen, and President Lin Sen. This was the era of nationalist government of China before the establishment of the People's Republic of China in 1945. Also present in the celebration of 1940 were a number of PID (Politieke Inlichtingen Dienst) or Dutch Intelligence Service, as the Dutch were always watchful of Chinese nationalistic movements. It is in this context that we should read a pro-Dutch article written in the 1940 anniversary book. The article expressed concern about the German occupation of the Netherlands on 10 May 1940 which endangered the Dutch royal family, and it also professed loyalty to the colonial government:

All subjects in good and willing heart must fulfil the responsibility to uphold the safety of the Netherland Kingdom, its colony and government! ${ }^{23}$

In 1942, however, when the Japanese occupation began, Ang Hien Hoo started a new page of history. All Chinese individuals and their organizations were

21 "Maksud berdirinya perkumpulan Tionghoa 'goena memadjoeken goena negri dan bangsa kita: 1) comite-comite menoenjang Khik Bing, Pakhwatkoen, Perang di Shanghai, Bahaja bandjir dan bahaja kelaparan dan laen-lane goena Tjokok kita; 2) dan laen-laen seperti kapentingannja kita di sini, penoeloengan kaoem miskin, kaoem penganggoeran dan wakil-walkil di dalam Raad-raad perwakilan'". (Tjoe Sing, L. Suma et al. 1935: 14.)

22 This was actually not a national anthem, but a nationalistic song deriving from one of the Chinese classical texts, Li Gi, which underlines the democratic ideal of the Chinese society.

23 "Semoea orang dari golongan jang baek, dengen perasa'an soetji serta ichlas bersedia hendak penoehken kewadjiban terhadep dan oentoek keslametannja Keradja"an Nederland, djadjahan dan permerentahannja!" ( Liem Thiam Kwie in Liem Thiam Kwie, Ong Tjing Poen, and Kwee Liang Dji 1940: 48, my translation.) 
lumped into one Japanese formed body called the Kyoku Shinkai. Ang Hien Hoo's infrastructure and inventory were confiscated and placed under this new body. There was a difficult negotiation with the Japanese authority to keep the hearse as the burial association could not function without it. All other activities were to be coordinated under the Japanese formed body. The Chinese Ang Hien Hoo activists had to abide by this policy, but they strategically nominated Hang Kan Hoen, a respected Chinese businessman, who was also among Ang Hien Hoo leading activists (his writings were published in the 25th anniversary book, and he served as the chair of the organizing committee of the 50th anniversary celebration).

When Indonesia proclaimed its independence, Ang Hien Hoo resumed its old name, status and regained its possessions. Soon, however, the organization had to adjust with the new nation state. On 4 December 1958, under the leadership of Siauw Giok Bie, Ang Hien Hoo was formally registered as a national (Indonesian) social organization for burial needs of its members. Those who were not registered as Indonesian citizens (either the citizens of PRC or stateless) still had their full rights as members, but were classified as "extraordinary" or honorary members.

The 50th anniversary celebration, as usual, started with the singing of a national anthem, but now instead of a Chinese song, the Indonesian national anthem, "Indonesia Raya" was sung. In place of the PID, the Mayor of Malang and the commandant of the military garrison of Malang were present in the celebration. In his speech, the Mayor of Malang congratulated that Ang Hien Hoo survived the turmoil of the Second World War and the revolution, especially that "in the tornado of democratic liberalism before our Highest Commander the President issued a decree to return to the 1945 constitution, in which there was a politicization of everything, it is amazing that Ang Hien Hoo remained loyal to its principle of doing social work". The praise was phrased almost as an implicit "threat" that, if in the past Ang Hien Hoo "had tried to deviously depart from its principle of doing social work, maybe Ang Hien Hoo would have now become a memory". ${ }^{24}$ The mayor then reminded Ang Hien Hoo to remain faithful to "Pantjasila" and the slogan abbreviated as USDEK, ${ }^{25}$ introduced by President Soekarno in 1960.

In the cultural politics of Indonesia in the 1960s, with Soekarno's anti-West

\footnotetext{
24 "Bahawasanja Ang Hien Hoo dalam gontjangnja 2 perang dunia, pasang surutnja keadaan akibat revolusi kita sendiri tetap tabah, tetap hidup, sangatlah mengagumkan. Bahwasanja dalam puting beliung liberalismenja demokrasi sebelum dengan Dekrit Presiden Panglima Tertinggi kita kembali ke UndangUndang Dasar 45, dimana petualangan, penyelewengan meradjarelela memperpolitisir segalanja, tetapi Ang Hien Hoo tetap pada azas sosialnya, menimbulkan rasa hormat jang sebesar-besarnja [...]. Kalau sekali pada waktu jang lalu Pengurus mentjoba menyelewengkan Ang Hien Hoo dari azas sosialnja, mungkin Ang Hien Hoo dewasa ini hanja tinggal dalam kenangan sadja". (Koesno Soeroatmodjo in Tjan Tan Soen 1960: 11, my free translation.)

25 USDEK = Undang-undang Dasar 1945, Sosialisme Indonesia, Demokrasi, Ekonomi Terpimpin, dan Kepribadian Indonesia (the Constitution of 1945, Indonesian socialism, Democracy, Guided Economy, and Indonesian Character). This slogan, usually abbreviated as MANIPOL USDEK (or the Political Manifesto - USDEK) was introduced in 1960, following President Soekarno's Independence Day speech on 17 August 1959.
} 
propaganda, Ang Hien Hoo's artistic choice of the Javanese wayang orang and the Sumatran Serampang 12 were favourable. During this period, Soekarno specifically targeted what he called "the ngak-ngik-ngok music, and "rock-nroll-rock-n-roll and ala cha-cha-cha dances", thus reiterating what the writer in 1935 Ang Hien Hoo anniversary book had complained against the Western influences. Koes Ploes, the Indonesian musical band which was popular as "the Beatles of Indonesia" was banned, so was the bell-bottom fashion of the youth in 1960s. To replace the ballroom dance popular amongst the Chinese elite in the 1950s, there was the traditional lenso (Menadonese courting dance) and the newly invented pergaulan dance. The Sumatran Serampang 12 was also popularized by many dance workshops springing up in the 1960s.

The cultural politics of the 1960s was to creatively form the "Indonesian character", a modernist reformulation of Indonesian traditional performing arts and music. Indonesian school children memorized songs from various islands, from Papua to Aceh. It is within this cultural politics that Ang Hien Hoo Wayang Orang Group catapulted at the national level (Figure 4). The preservation of Chinese music and arts in Ang Hien Hoo's activities did not contradict Soekarno's cultural politics, as China was considered an Asianfriendly ally. This was also the time, when Soekarno was launching the NASAKOM (Nasionalisme, Agama, dan Komunisme) policy of integrating nationalism, religion and communism. In his battle against "Western imperialism" Soekarno established a good rapport with the communist PRC.

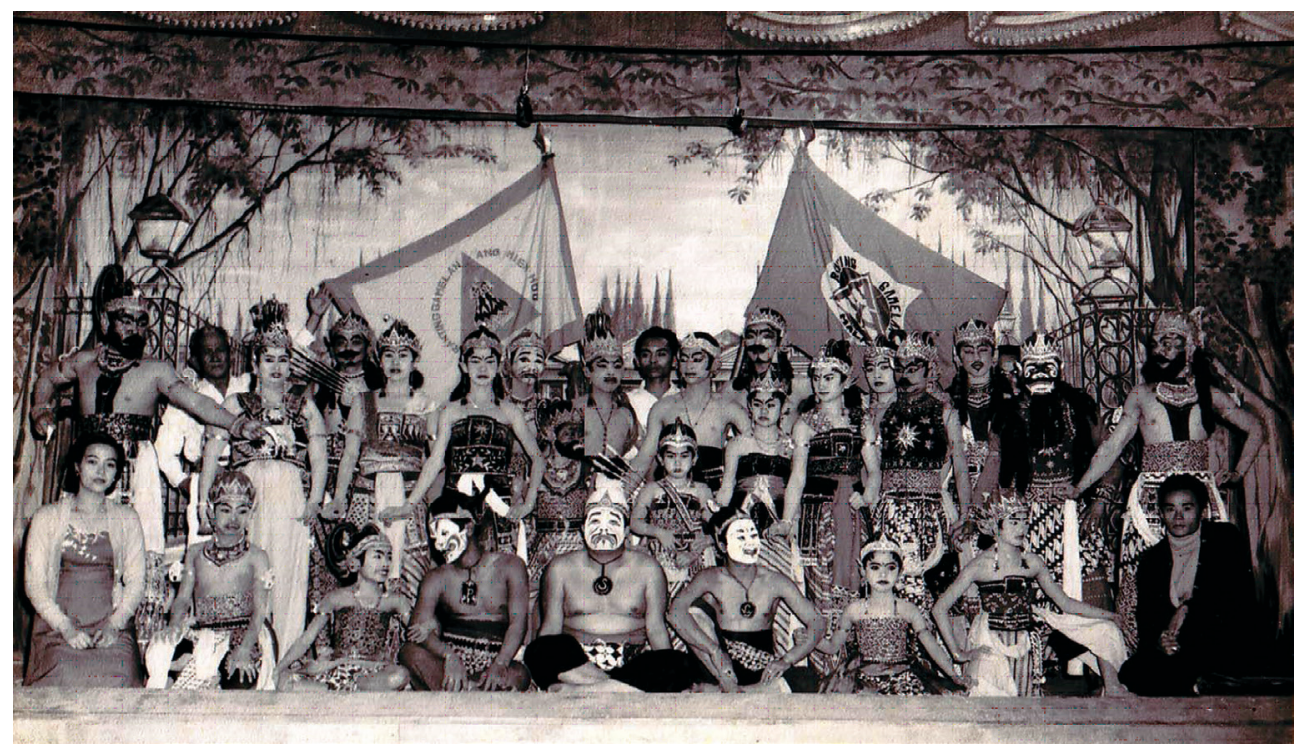

Figure 4. The All Chinese Wayang Orang Division of Ang Hien Hoo in 1960s (photographed by Ong Kian Bie, courtesy of Ong Ay Ling).

The political crisis on 30 September 1965, however, turned the table over. The discovery by the rising General Suharto of the murder of the seven army 
generals in a deserted well in the outskirt of Jakarta served as an impetus for communist cleansing hysteria all over the country, which killed around 500.000 people, civilians as well as military. In 1966 General Suharto took over the government from the ailing Soekarno, and the anti-communist regime called the New Order began.

The impact of the crisis to the arts and cultural scene was grave. Any artist of performing arts who once participated in events sponsored by the leftist organization was interrogated, tortured, jailed without trial, or killed. Organizations, which were considered to have leftist leaning were banned, the leaders and members detained. One organization, which was founded and supported by Chinese Indonesians who advocated on citizenship rights, BAPERKI (Badan Permusyawaratan Kewarganegaraan Indonesia), was banned. Siauw Giok Bie, the director of Ang Hien Hoo from 1958-1965, who was also a leader of the East Java branch of BAPERKI, was detained. The organization faced a critical stage.

With the communist cleansing, the political ties with the PRC were severed. In the effort to save Chinese Indonesians from being linked to the communist China, a number of Chinese Indonesian activists suggested the assimilation policy. The military regime took it up and, on this ground, banned Chinese language and culture from public display and urged the Chinese to change their names into non-Chinese sounding names. With this racial cultural politics, Ang Hien Hoo could no longer put Chinese music and performing arts into public display. At the same time, wayang orang activities decreased like other cultural activities of the larger society in the wake of the 1965 political trauma, as many performing arts activists who were considered leftist or had been hired by leftist organizations were detained.

The Ang Hien Hoo burial organization survived the 1965, amidst continuing insecurity against allegation of its ties with the banned BAPERKI and "the communist infiltration" - a loaded watch-word of the New Order regime. Its name was changed into Yayasan Panca Budhi. The portrait of Siauw Giok Bie was taken down from the row of portraits of its directors in the office of the burial association, and his period of service was left blank in the official history of Ang Hien Hoo afterwards. ${ }^{26}$ In order to save the organization, a Chinese Indonesian dentist from the military, Col. Ong Tjong Bing, was nominated as director from 1978-2005. Throughout the 32 years of the New Order era, the burial association continued to operate, but the wayang orang cultural section was closed in the mid-1980s.

Two years after the Reformasi movement toppled down the Suharto government, the Indonesian fourth President, Abdurrachman Wahid, lifted the ban against Chinese language and culture in 2000. With China rose as a new emerging economy in the 21st century, lion and dragon dances from Chinese temples all over Indonesia, including the En Ang Kiong Temple, returned to the public space. The En Ang Kiong's Mandarin classes attracted students from

26 The historical erasure was discussed by Abdul Malik (2016b) in "Ang Hien Hoo dan Siauw Giok Bie" (in: Dari Ang Hien Hoo, Ratna Indraswari Ibrahim hingga Hikayat Kebonagung). 
wider population from non-Chinese background. After President Megawati declared the Chinese New Year as one of the national holidays, celebration of Chinese arts and culture entered into malls. Everything Chinese is for sale.

It is within this new cultural politics, that the Wayang Orang Section of Ang Hien Hoo, now called Wayang Orang Panca Budhi, is revived. By now, most of the ex-senior wayang orang performers have passed away, the younger generation were in their fifties, and a great number of them had left Malang. Interviewed separately, most ex-performers were still keen in the wayang orang art, although they did not think they could revive the group. Sinta Dewi, a widowed mother of three in Malang, had a different opinion. ${ }^{27}$ She was an ardent fan of Ang Hien Hoo in her young age, and she was convinced to revive the tradition. She chaired the Wayang Orang Section in the 1990s and recruited her son, daughter, and granddaughter to join the wayang orang group with different names (Bhara Pratama, Slogo Budoyo). She collected accessories for the wayang orang theatre in her house and as they accumulated, rents her collection not only for the Panca Budhi performance, but also for other wayang orang groups in Malang.

Sinta Dewi's effort in reviving the wayang orang tradition was not without difficulty, especially in financial terms. In the new decentralized cultural politics in Indonesia, however, each region was looking for their authentic cultural roots and identity, and Javanese wayang orang was not considered as unique for a city in East Java, as compared to the Malang mask dance, ludruk or ketoprak. The wayang orang is considered as the arts originating from central Java. Thus, local government sponsorship is not much to be expected. With the revival of Chineseness, the barongsay or lion dance or the Chinese music and traditional dances are more in demand. With rising capital from China, it is easier to find sponsorship for Chinese arts and dances than for a wayang orang group. The ingenuity of inviting the lion dance troupe of the En Ang Kiong Temple to replace the "tiger" in the performance of the Panca Budhi Wayang Orang Group was an ingenious creativity to connect to this new energy from the Chinese revivalism.

The creative devise was not without grounds, not only because the Ang Hien Hoo (or Panca Budhi) burial association has always been linked to the En Ang Kiong Temple, but their arts and cultural expression have always been interlocked. The En Ang Kiong Temple, which houses its own gamelan orchestra, has often been the "borrowed site" for the Ang Hien Hoo players to practice. On the other hand, the Ang Hien Hoo monkey troops and other wayang orang characters have always been an integral part of the parade ritual to carry the temple gods during the temple anniversaries. In the past, Ang Hien Hoo anniversary parties and the procession of the Ang Hien Hoo five elders also started in the temple and were accompanied by the temple lion dance. This close link between the barongsay and the ketek ogleng (the monkey troops in the wayang orang group) signifies the symbiosis between 
the Chinese heritage in Indonesia and the local performing arts, as in the case of the gambang kromong and the tanjidoor in Betawi.

\section{SOCIAL NETWORK AND CULTURAL BELONGING}

Ang Hien Hoo had started with the motivation to gather "dispersed" Chinese with their diverse background in Malang, East Java. There was a feeling of urgency to educate and facilitate the Chinese settlers in caring for the dead in distant land. As the organization provided a space for its members to pursue their different hobbies for leisure, Ang Hien Hoo gradually evolved to be a means for nurturing their longing - not for their Chinese homeland - but for an imagined universe of the wayang orang, a Javanese dance theatre originating from Central Java. The popularity of this Javanese dance spread to the east as traveling groups called wayang tobong went from one town to another, performing in the market fairs. Moreover, East Javanese culture comprised three cultural forces from the Central Javanese court culture (Mataraman), the Madurese (Pandalungan) to the indigenous East Javanese (Arek). The Chinese who populated Malang in the 1950s, when the Wayang Orang Section came into being, mostly came from neighbouring towns (Kediri, Nganjuk, Blitar, Pasuruan) with strong Mataraman influence.

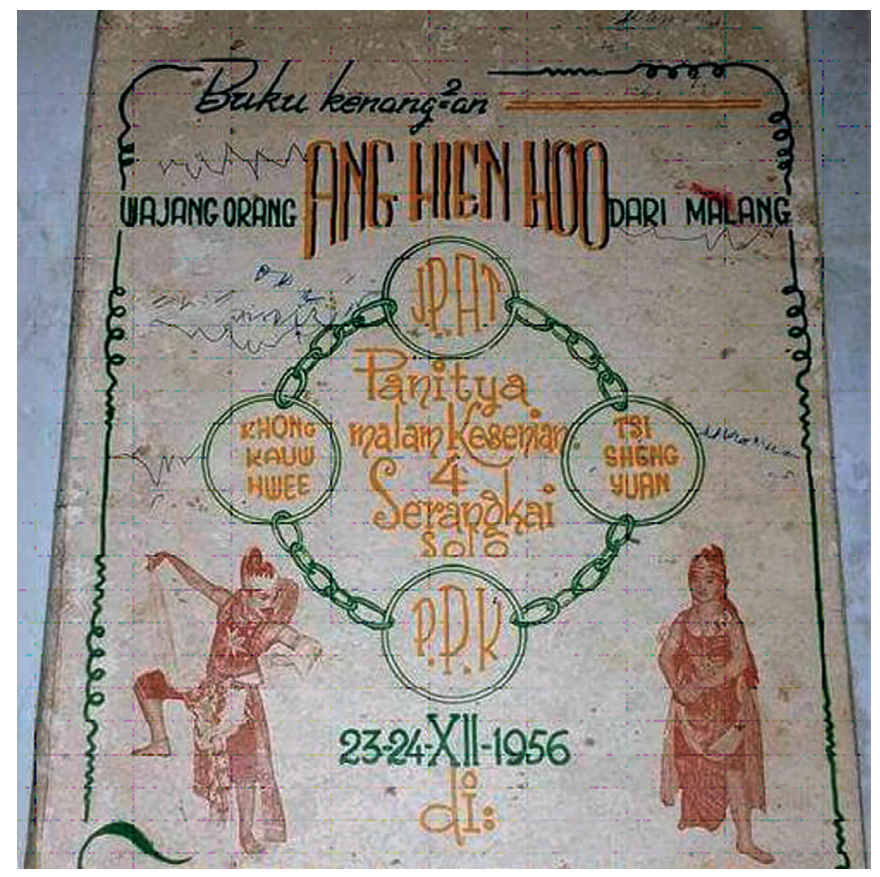

Figure 5. Ang Hien Hoo Program Book for their performance in Surakarta, 1956 (Courtesy of Bagus Ninar S.).

Ang Hien Hoo was not unique, as a number of Chinese wayang orang theatre groups mushroomed in Central and East Java, with the most wellknown groups in Solo and Semarang, Central Java, and Surabaya, East Java 
in the 1940s to 1960s. These were cities with relatively high concentration of Chinese settlers in Java since the late nineteenth century, with a fast growth of Chinese population in the early twentieth century. The Ang Hien Hoo anniversary books show the strong network amongst the Chinese in Java, not only through economic cooperation, but also social and cultural activities. Similarly, in the 1956 program book of Ang Hien Hoo's performance in Surakarta (Figure 5), four social organizations in Surakarta were mentioned as organizers. It was common among the Chinese organizations to invite arts and sports groups from other towns to join a festival, or in the case of the Chinese wayang orang, to invite performers from other cities to join their performances. One best known Ang Hien Hoo's prima donna in the late 1950s and early 1960s was Nelly Ie, a daughter of an activist of a Chinese wayang orang group in Surabaya, and a maker of wayang orang costumes for Ang Hien Hoo. In late 1960s, Jhon Tejakusuma, a senior wayang orang performer and a director, also from Surabaya, performed with the group when Ang Hien Hoo performers dwindled in the aftermath of the 1965 communist cleansing tragedy.

The attraction to wayang orang was a form of acculturation, a "love that came from being exposed to" (tresno jalaran kulino), as Jhon Tejakusuma said. ${ }^{28}$ Born in 1940, Jhon learned Javanese dances when he was nine years old. He fell in love with the wayang orang theatre as he watched their performances in Surabaya, and got more deeply hooked into the world of wayang from the wayang comics popular in the $1950 \mathrm{~s} .{ }^{29} \mathrm{Jhon}$ joined a group in a youth centre near his home and was soon recruited by a talent scout for a Chinese wayang orang theatre group in Surabaya called Perbusa (Perhimpunan Budaya Surabaya, or the Surabaya Cultural Association). Later, he became a lead performer, a director, and eventually formed a group of his own in the 1970s. For Jhon, to learn wayang orang was to understand the whole system, philosophy and language. While his mother tongue was a mixture of Indonesian, strongly coloured by colloquial Javanese, mixed with Hokkien, Dutch, and English vocabularies, he soon learned to master six levels of Javanese language and became a teacher of Javanese language in a Junior High School in Surabaya. Not all of the Chinese wayang perfomers went as deep as Jhon in the Javanese language and culture, but the process of being lured to the world of wayang orang was similar..$^{30}$ Families who loved the art brought their children and grandchildren to watch or join the theatre, and the passion was handed down from one generation to the next (Figure 6). Parents were ambitious in training

28 Telephone interview with Jhon Tejakusuma, 6-12-2016 and 11-12-2016.

29 The Mahabharata comic series written and drawn by R.A. Kosasih in 1955 was widely popular in Java and helped popularize wayang stories amongst adults and children. It was soon followed by the Arjuna Wiwaha comic series by Ardisoma in 1956.

30 Karts Kies Slamet, a senior performer and director of Wayang Orang Bharata, Jakarta, who has trained many Chinese wayang orang performers, believed that "the Chinese will go all out to study wayang when they fall in love with the art. They show curiosity and ambition to acquire all that they can learn from the best wayang orang teachers they can afford to pay" (interview, Jakarta, 6-12-2016). Slamet's father used to work as a wayang orang costume maker for Nelly Ie's father in Surabaya, and therefore was often provided costumes for Ang Hien Hoo in Malang. 
their children to dance, and often competed in having their daughters, sons, and grandchildren play the wayang orang roles (Figure 7).

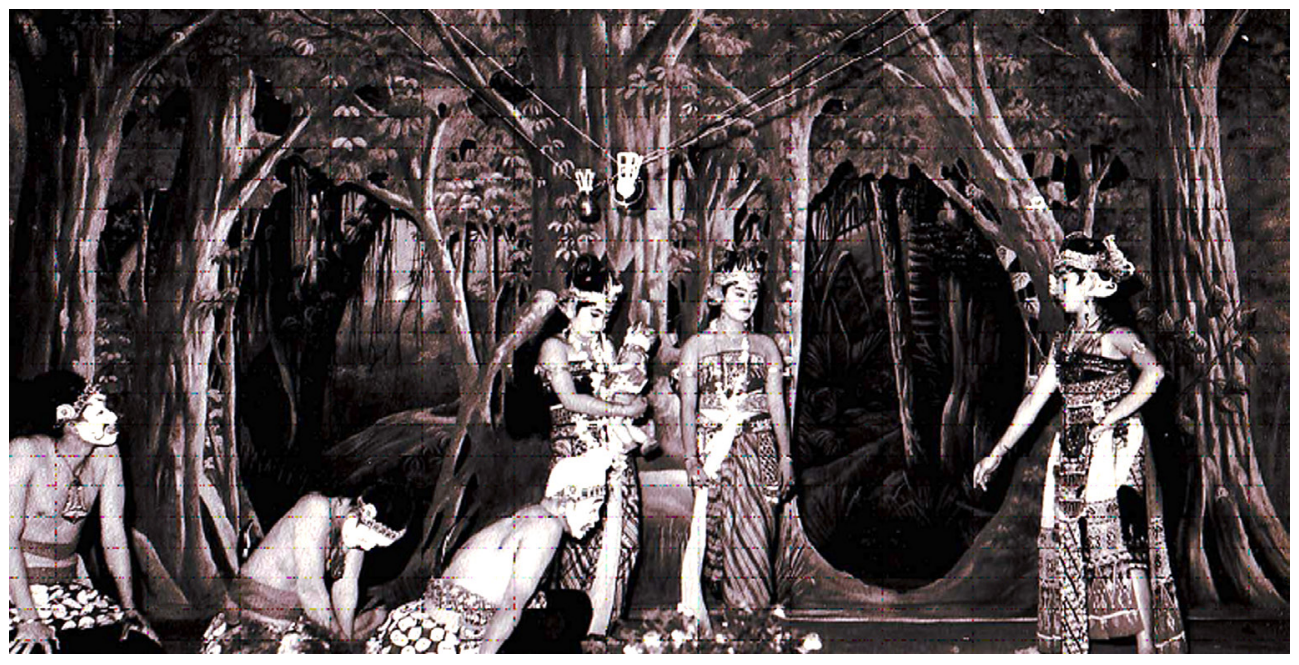

Figure 6. The wayang orang scene in the 1960s (photographed by Ong Kian Bie, courtesy of Ong Ay Ling).

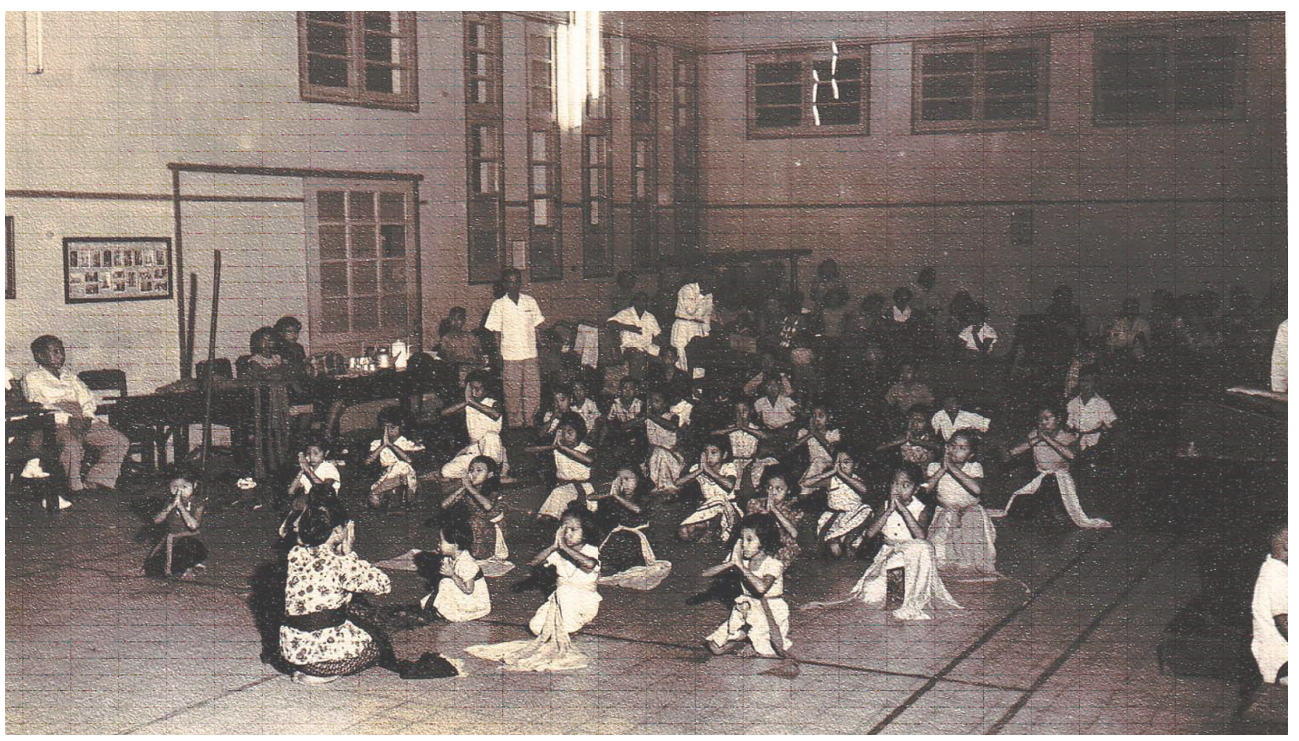

Figure 7. Children during dance training in the 1960s (photographed by Ong Kian Bie, courtesy of Ong Ay Ling).

Albeit their acculturation, the fact that Ang Hien Hoo was an all Chinese wayang orang group defines the nature of its limited interaction with nonChinese. Many gamelan players and the karawitan (Javanese tembang singers) and a few players, who were friends and neighbours of the Ang Hien Hoo activists, were of Javanese descent. So was the teacher, Suprapto Salya, 
who was recruited from Yogyakarta. Whenever Ang Hien Hoo staged a performance, they attracted audience from all backgrounds. As they joined wayang orang festivals and competitions elsewhere, they met other wayang orang groups. It was noted that during the golden decade of Ang Hien Hoo from mid-1950s to mid-1960s, there were other wayang orang groups in Malang (as they were in other cities). One of which was Sedyo Budoyo with its own theatre called Flora, owned also by a Chinese businessman. But the performers of the group were non-Chinese. ${ }^{31}$

The formation of the all Chinese wayang orang theatre could not be separated from its inception from the Chinese burial association that was naturally exclusively Chinese in the segregated system of the colonial period. Psychologically, for the players, the all Chinese group gave a comfort zone of learning a Javanese art with people for whom Javanese was not their mother tongue. ${ }^{32}$ The mesmerizing world of the wayang orang did immerse and unite the heterogeneous Chinese settlers in Malang, yet it did not guarantee a social integration with the non-Chinese communities.

At the same time, their branding as an all Chinese wayang orang group gave Ang Hien Hoo a leverage locally as well as nationally. When the Ang Hien Hoo troupe came out second in the Surakarta Wayang Orang Festival in 1956, reviewers criticized their accent, but praised the effort of the Chinese in learning to chant in refined Javanese language. ${ }^{33}$ They were also honoured with the invitation from President Soekarno to perform in the Jakarta and Bogor palaces, in 1958 and in 1961. The President awarded the lead dancer, Nelly Ie, with an Indonesian name, Ratna Djuwita. Inspired by this, Melly Oei, who performed as Ratna's female partner, also took up an Indonesian name, Ratnawati, upon the President's blessings (Figure 8). Soon afterwards, Ratnawati was to perform in a number of films directed by the Chinese director from Malang, Fred Young, acting side by side with leading national actors, such as Bambang Irawan, Nani Wijaya, and Fify Young. ${ }^{34}$ The career span of the female performers of Ang Hien Hoo was relatively short, as they stopped performing once they were married or continued their studies. For all the performers, this short-spanned moment of national limelight was a lifetime experience. They remembered how they danced on the same stage as Soekarno's daughters and sons, and how they were welcomed in the state palaces in Jakarta and Bogor. ${ }^{35}$ As a minority, the Chinese felt greatly appreciated. The 1960 anniversary book rightly expressed the pride that their wayang orang group had given the Chinese Indonesians "a good name".

\footnotetext{
31 Discussion with ex-Ang Hien Hoo performers and wayang activists in Malang, 6-11-2016.

32 Telephone interview with Jhon Tejakusuma, 11-12-2016.

33 See media coverage on the reception of Ang Hien Hoo when they performed at the Surakarta place: KSN (1956) "Nonton wayang orang Ang Hien Hoo", Pancawarna pp. 30-32, (http:/ / tjamboek28.multiply.com/photos/album/164/Wajang_orang_ANG_HIEN_HOO, accessed 14-8-2009).

34 Interview with Ratnawati, Surabaya, 7-12-2016.

35 Interview with Go Han Iem, Surabaya, 7-12-2016; and Ratnawati, Surabaya, 7-12-2016.
} 


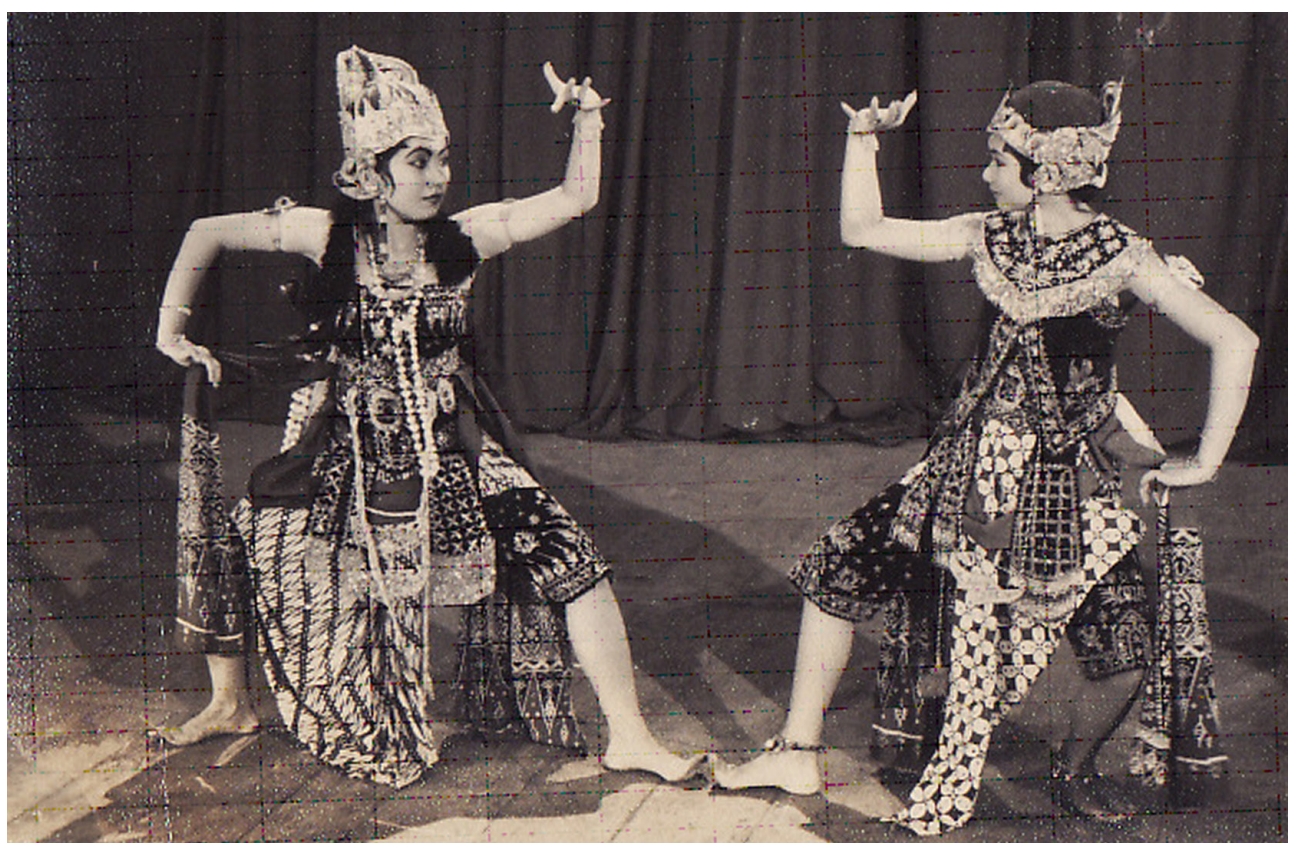

Figure 8. Ratna Juwita and Ratnawati dancing Menakjinggo Dayun, performed at the Bogor Palace in 1959 (courtesy of Ratnawati).

The exclusive "Chinese" group dwindled in the years after 1965 and became slowly depleted of its players, who were either married or busy with their study and careers. There were two other younger generations after Ratna Juwita and Ratnawati. When Sinta Dewi revived the group in 1980s, she had to rely on children dancers, instead of young adults, and mostly from nonChinese backgrounds. As small cigarette companies in Malang were replaced by bigger conglomeration, sponsorship for performing arts was no longer readily available. By that time, leisure and lifestyle of the middle classes had changed. Television had taken up time previously spent for traditional theatre and dances.

\section{Ang Hien Hoo Wayang Orang Group as amateur Club outside the Market PLACE}

Being a non-profit organization, the burial association left the patronage of the arts to the initiatives and support of its members, and the society at large. In this way, the patronage operates outside the capital in the form of leisure or hobby clubs, mobilized in events such as charity and fundraising activities. Supported by fans and lovers of the arts, who happen to have the means to support it, the patronage is dependent on social network and the ability to mobilize such a network to promote the arts. ${ }^{36}$

36 Performers were never paid for the performance. In fact, they contributed in paying for the fee of the instructors. During special rehearsals for performance and meals were provided and the artists would be given a small souvenir as a token of appreciation. The chair of the division 
This patronage system of the amateur art is different from the professional management of other Javanese performing arts discussed by Perlman (1999), in which professional traditional artists were paid by their patron or direct customers. The engagement of this amateur group with the market is in selling tickets for the general public, which is done, again through social networking instead of a professional event organizer (Tickets are generally distributed by members and friends). The problem of this system of engaging with the "public" is that people might buy the tickets to help out friends, and not because they want to attend the performance. Tickets might be sold, but audience cannot be secured. ${ }^{37}$

Remaining outside the capital gives a space for more flexible civic engagement. At the same time, it also creates insecurity in terms of financing and organizational matters. While openness and flexibility in accommodating initiatives is one source of Ang Hien Hoo's resilience in surviving the social and political changes, creative expansion of interest can cause organizational problem. In the 1950s and in 2000s the expansion of special interest divisions of the Ang Hien Hoo organizations posed management problem to the unity of the association, as each division had to rely on their own efforts in procuring and managing funds for their activities. In 1958, the problem became so complicated that the association had to form a special committee to solve administrative confusion in managing these activities.

Although the speech of the Mayor of Malang in the 1960 indicated support of such art, the state - meaning the central as well as local government - has not played a role in supporting the group. It is different from the case of other local performing arts, such as the Topeng Malang (The Mask Dance of Malang), or the ludruk, which are considered to be "authentic" local cultural expressions, and therefore requiring the protection of local government to preserve cultural legacy. The stereotype of the Chinese as occupying economically advantageous positions resulted in less opportunity for the group to access government funding. During the 1950s, in the heyday of the Ang Hien Hoo Wayang Orang Group, President Soekarno did invite them to play at the palace. However, the performance was dedicated as a charity or fundraising activity to help disaster victims, and therefore was more an act of civic engagement of the group, and not a state patronage. It is interesting to compare this with the amateur Chinese opera tradition in Singapore, which was prioritized from the professional ones to receive Singaporean state patronage (Lee Tong Soon 2007). ${ }^{38}$ In Singapore, according to Lee Tong Soon, "the fact that amateurs can

would do special fundraising to cover all the cost. Today the cost of performance can reach up to USD 2.000, and tickets ranged from. In the past, during the anniversary celebration of the Ang Hien Hoo burial association, performance was considered as contribution (thus not being funded by the burial association).

37 What often happened in this system is that it heavily relied on the family and friends of the amateur dancers both for financial support as well as for being the loyal audience for the art.

38 It is interesting to notice that in Singapore the Chinese amateur opera groups still operate within "linguistically defined" groups, just like the initial Cantonese opera club house in 
afford a leisure pursuit of music reinforces class distinctions, and their socioeconomic power serves to legitimize the art form" (Lee Tong Soon 2007: 413). In Ang Hien Hoo case, the Javanese traditional art served more as a cultural space, through which members, from the elite to the poor found a shared cultural home. In this cultural space, the economic contribution of the rich made up for the participation of the poor. Although leisure was a luxury, the Chinese from the lower middle class background did make time to participate for recreation and cultural needs - especially the Chinese migrants from rural East Javanese areas in the early twentieth century up to the 1970s.

The Ang Hien Hoo Wayang Orang Section was just one among the many cases of Chinese patronage of local traditional arts. Chinese patronage of the keroncong music can be traced from the use of the songs composed by the keroncong maestro named Gesang by the Malang born Chinese director, Fred Young, in his Bintang Surabaya theatre group. In the nineteenth century, Tan Khoen Soei in Kediri, southwest of Malang, was one of the most important publishers of Javanese scripts. As early as the eighteenth century, the Chinese have written Chinese legends and stories in Javanese using Javanese scripts. The way the Peranakan Chinese develop Batik industries and East Javanese culinary tradition has been widely discussed. The patronage continued to generations. Mrs Tirtoutomo, a Chinese Indonesian philanthropist (born in 1934), the wife of an Indonesian pioneer of the bottled water industry, sponsored monthly performance of short version of wayang kulit (shadow puppet)/wayang orang at her Griya Tirtadi Auditorium in Jakarta from 2008-2010. Similar to the Chinese who became wayang orang lover, Elly Hong Tjwan (born in 1940) an ardent lover of keroncong music, was exposed to keroncong music since she was young. She mobilized her network among the elite businesses for fund raising to support aging keroncong music singers and promote the traditional art for the younger generation.

\section{CONCLUDING REMARKS: THE PAST IN THE PRESENT}

As a burial association, Ang Hien Hoo (now the Panca Budhi) in its 106 years has managed to create a meeting place for the diverse Chinese population in Malang and accommodate their heterogeneous cultural interests and expressions. Throughout the time, the organization has tried to maintain a link, albeit problematic and fractured, with an imagined Chinese origin, as it grounds itself and engages with the continuously changing socio-political and cultural forces of the local environment. In upholding the "democratic" principle to support the needs of the members, the burial association had at times expanded its role from performing a routine burial service to be a patron of sports and arts, including Chinese and local traditional arts.

The fact that the Ang Hien Hoo Wayang Orang Division survived both

Malang in the early twentieth century. Like the Singaporean Chinese club houses, Ang Hien Hoo served as both as a training space as well as a locus for social activities (Lee Tong Soon 2007: 402). In contrast, however, Ang Hien Hoo also served as the meeting place of Chinese migrants from all backgrounds. 
the internal hassle as well as the external challenges also suggests that it must have supported by a certain "public" or audience or supporters who subscribe to their activities. Like the case of other arts, this public art fluctuates from time to time, especially at times when the choice of the arts was or was not in line with the cultural politics of the time. During the 1950s and 1960s the Ang Hien Hoo all-Chinese Wayang Orang Crew reached its peak of popularity, like similar groups all over Java. ${ }^{39}$ After the Reformasi, the public dwindles for various reasons, one of which was the decline of traditional arts in general in facing the onslaught of new kinds of globalized popular culture. Another reason is the surge of regionalism, the search for the authentic and original art to represent each region.

Within the present cultural politics, in which the Chinese arts are represented in the public discourse by distinctly red and gold Chinese characters, each region competes in finding their authentic arts, and the Nation-State jealously guards the ownership of songs and dances, such crossboundary and fluid exchanges and adoption of arts tend to be forgotten. It is, therefore, critical to intervene with such regressive cultural politics by foregrounding an alternative praxis as exemplified by the Ang Hien Hoo all-Chinese Wayang Orang.

It is in this position of belonging neither here nor there, that the Ang Hien Hoo Wayang Orang Division asserts itself in a non-essentializing way within the parochial cultural politics of the decentralization era. Without giving up the arts, which is close to their heart, the Chinese patrons of the Ang Hien Hoo Wayang Orang Division negotiates with the pressure of the market (read: what the audience demand) by ingenious compromises, such as collaborating with the En Ang Kiong's lion dance. ${ }^{40}$

The mixing of the Chinese lion dance with the Wayang Orang performance also signifies the close interconnection between the Chinese temple in Malang as well as in other places with local performing arts, as the temple festivities in the past had always incorporated local music and performing arts. It is important to note here that, compared to the other choice of arts, which the Chinese in Malang have embraced, such as the modern dance and theatre, it is the wayang orang theatre, a Javanese art - located at the heart of the Chinatown area - that in the 1950s and 1960s managed to draw Chinese population from all backgrounds, the Chinese or the Dutch educated, the Peranakan and the totok, the poor and the rich.

The basis of Ang Hien Hoo's amateur art in the past was the need of a particular diaspora community, which is no longer relevant in today's globalized market place with individualized consumption of arts as commodities. However, the urban space in the twenty-first century Indonesia still allows some possibilities for a different kind of more inclusive

39 In the 1950s and 1960s, there were various Chinese wayang orang groups in Central and East Java. They regularly joined festivals, such as the one held in Surakarta in the mid-1950s.

40 One can compare this with the compromises of the artists of traditional performing arts have to make by introducing the pop genre campursari in their performances to attract audience. 
communitarian space to support this amateurish, leisure time art to exist. These venues are among others city arts festivals. Still in line with competing regionalism, city arts festivals are celebrated more in a multicultural, and less essentialist way. The nature of this new civic space in its relation to the civil society, the state, and the marketplace in its multicultural context still needs to be theorized, but such space promises new possibility for amateur arts to survive.

A new generation of young people from Malang, from diverse ethnic backgrounds, has shown a genuine interest in recovering the heterogeneous cultural legacy of Malang. Dwi Budi Cahyono, head of the Malang Arts Council, worked to preserve not only old building and archives, but also to engage with new enterprising young people in mobilizing local cultural resources of the city. In the same line, a free-lance writer, Dukut Widodo, in 2004 published the two volumes of Malang Tempoe Doeloe books in a playful, colloquial Malang dialect, digging the contribution of the Chinese, the Arabic, the Indians, and Malang literati in building the cultural and intellectual milieu of Malang, without subscribing to racial stereotyping.

Competing with Jember, a small city south of Malang, which has found a unique annual fashion parade as its trademark ${ }^{41}$ Malang now holds its annual festival, called "Malang Tempoe Doeloe" or "Malang Return". For a whole week, the Ijen Boulevard, one of the most well-known elite residential areas since the colonial times, is changed into a historical period of the past. The "Malang Return", or the past in the present form, is a kind of multicultural bazaar, where business, charity, and civic engagement are occurring hand in hand. The revived wayang orang initiated by ex-Ang Hien Hoo activists contributed to this new urban civic space by showing that traditional arts are free to be owned by anybody regardless of racial and cultural background. Within these annual festivals, the group would perform (as an unpaid contribution) with its new creative experimentation. Down southeast in the Chinatown area, the En An Kiong Temple in July 2010 celebrated its 185-year anniversary. Behind the lion dance, the Ang Hien Hoo wayang orang monkeys joined the procession of the temple Gods.

The history of the Ang Hien Hoo Wayang Orang Group shows the tenacity, by which the older generations of Chinese wayang orang performers held on to their art, in the face of political and economic difficulties, from the Dutch era, Japanese period, to the present. They treaded the insecure waves of political changes with cultural adaptability, flexibility and openness in partaking and sharing the traditional arts, which they had grown to love. The 21th century brought different challenges for the sustainability of the hobby, economically as well as politically, not only from changing lifestyle and consumer culture, but also from the rise of xenophobia and racism, globally as well as in nationally. Indonesia towards the end of 2016 saw the rise of anti-Christian

41 In the 21th century Indonesia, festivals in city, town and village levels have become a popular means for promoting local cultural heritage and creative economy. Jember Fashion Festival was amongst the first successful ones that set the trend. 
and anti-Chinese sentiments. ${ }^{42}$ It was in this climate that some humanitarian and arts activists in Malang gathered Ang Hien Hoo ex-performers, not only to remember the patronage of the Chinese for the traditional art, but also to invite the younger generation to continue the practice. A plan was made to have a three-generation wayang orang performances as a reunion event in the wake of the Chinese New Year 2017 in Ang Hien Hoo Auditorium, supported by ex-performers and wayang orang activists in other cities, in particular Jakarta, Surabaya, and Malang.

The existence of Ang Hien Hoo has been rediscovered by the local media a few years before, and by the national media in 2016 (Malik 2013, 2014, 2015, 2016b; Suhandak 2013; Media Budaya Pasar Senggol 2013a, 2013b, 2013c; Tempo 2016a, 2016b). ${ }^{43}$ In these reports, President Soekarno's attention to this group was highlighted. Both Soekarno's attraction as well as the media's rediscovery of Ang Hien Hoo reveal the double-bind that characterizes the position of the Indonesian Chinese. On the one hand, their embrace of the Javanese art is their centre of attraction, a positive appraisal of their cultural assimilation. On the other hand, their Chineseness makes their very appeal, underlining their nature as an exclusive, racially marked entity. In other words, this double bind also speaks of the limit both of the cultural and structural assimilations of the Chinese-Indonesians. The fact that activists, journalists, and intellectuals of diverse backgrounds worked together in planning the Ang Hien Hoo reunion in 2017 signals a new phase of a more inclusive civic space. How this space is expanded for a sustainable integration remains to be seen.

\section{REFERENCES}

Brandon, James R. 2009. Theatre in Southeast Asia. Cambridge/Massachusetts: Harvard University Press.

Buku kenang-kenangan kirab ritual dan budaya peringatan HUT kelenteng Eng AN Kong - Malang ke 182 (1825-2007) (2558 Ni Lak Gwee Ce Lak - 19 Juli 2007). Malang: Wika En An Kiong.

Charney, Michael W., Brenda S. A. Yeoh, and Tong Chee Kiong. 2003. Chinese migrants abroad; Cultural, educational, and social dimensions of the Chinese diaspora. Singapore: NUS Press and World Scientific Publishing.

Handinoto, Paulus H.S. 1996. Perkembangan kota dan arsitektur kolonial Belanda di Malang. Surabaya/Yogyakarta: Universitas Kristen Petra and Penerbit Andi.

42 A massive demonstration was launched against the double minority of a Christian Chinese governor demanding his trial and arrest under the blasphemy law against one of his public speech. Anti-Chinese and anti-Christian atmosphere was on the rise towards the end of 2016, not only in the capital, but throughout areas with the majority of Islamic population, including in Malang.

43 A key figure in this rediscovery of Ang Hien Hoo is Abdul Malik, a journalist of Arabic descent, who has consistently written on Ang Hien Hoo since 2014, and who initiated the reunion after successfully tracking and contacting the ex-performers who are residing in Jakarta, Surabaya, and Malang. 
Hoon Chang Yau. 2008. Chinese identity in Post Suharto Indonesia; Culture, politics, and media. Portland: Sussex Academic Press.

KSN. 1956. “Nonton wayang orang Ang Hien Hoo", in: Pancawarna pp. 30-32. [Retrieved from: http:/ / tjamboek28.multiply.com/photos/album/164/ Wajang_orang_ANG_HIEN_HOO, accessed 14-8-2009].

Lee Tong Soon. 2007. "Chinese theatre, Confucianism, and nationalism; Amateur Chinese Opera Tradition in Singapore", Asian Theatre Journal, Vol. 24/2 (Fall): 397-442.

Liem Thiam Kwie, Ong Tjing Poen, and Kwee Liang Dji. 1940. Gedenkboek Jubelium - 30 Taon Vereeniging Ang Hien Hoo Malang, 1910-1940. Malang: Ang Hien Hoo.

Malik, Abdul. 2013. "Sang Primadona", Media Budaya Pasar Senggol Vol. 1/1 (August): 17.

Malik, Abdul. 2014. "Bung Karno dan Ang Hien Hoo". [Retrieved from: http:/ / www. kompasiana.com/kurakurabiru/bung-karno-dan-ang-hienhoo_54f416b8745513902b6c8594].

Malik, Abdul. 2015. “Seabad Wayang Orang Ang Hien Hoo”. [Retrieved from: http:/ / www. kompasiana.com/kurakurabiru/seabad-wayang-orangang-hien-hoo-di-malang_5535b4686ea834ff25da42d5].

Malik, Abdul. 2016a. "Bertemu Bu Shirley Kristiani Widjihandayani (Tjhwa Hiang Nio), Malang Post 20 November 2016. [Retrieved from: http:/ / malangpost.net/ragam/resensi/bertemu-bu-shirley-kristianiwidjihandayani-tjhwa].

Malik, Abdul. 2016b. Dari Ang Hien Hoo, Ratna Indraswari Ibrahim, hingga Hikayat Kebonagung. Mojokerto: Pustaka Banyumili.

Media Budaya Pasar Senggol. 2013a. “30 tahun Ang Hien Hoo, Jubelium yang meriah", Vol. 1/1 (August): 13-14.

Media Budaya Pasar Senggol. 2013b. “Ang Hien Hoo; Bung Karno akhirnya memanggil kami", Vol. 1/1 (August): 6-9.

Media Budaya Pasar Senggol. 2013c. "Tahun 1910 Ang Hien Hoo sah berdiri", Vol. 1/1 (August): 12.

Perlman, Marc. 1999. “The traditional Javanese performing arts in the twilight of the New Order; Two letters from Solo", Indonesia Vol. 68 (October): 1-37.

Rustopo. 2007. Menjadi Jawa; Orang-orang Tionghoa dan kebudayaan Jawa di Surakarta, 1895-1998. Yogyakarta: Ombak and Yayasan Nabil.

Rustopo. 2008. Jawa Sejati; Otobiografi Go Tik Swan Hardjonagoro. Yogyakarta: Ombak and Yayasan Nabil.

Shaick, A. van. 1996. Malang; Beeld van een stad. Purmerend: Asia Maior.

Soedarsono. 1984. Wayang wong. Yogyakarta: Gadjah Mada University Press.

Suhandak, Arip. 2013. "Arjuno Wiwoho untuk Bung Karno", Media Budaya Pasar Senggol Vol. 1/1 (August): 10-11.

Tempo. 2016a. “Legenda Ang Hien Hoo”, Tempo 21-3-2016: 56, 57.

Tempo. 2016b. “Sang Primadona Terakhir", Tempo 21-3-2016: 58.

Tjan Tan Soen (ed.). 1960. Lustrum ke X, 50 tahun Ang Hien Hoo Malang, Sept 1910-Sept 1960. Malang: Ang Hien Hoo. 
Tjoe Sing, L. Suma et al. (eds). 1935. Gedenkboek 1910-1935; 25 taoen berdirinja Ang Hien Hoo Malang. Malang: Comite Jubileum 25 Taon Vereeniging Ang Hien Hoo Malang.

Twang Peck Yang. 1997. The Chinese business elite in Indonesia and the transition to Independence (1940-1950). Kuala Lumpur/Oxford/New York: Oxford University Press.

Um, Hae-kyung (ed.). 2005. Diasporas and interculturalism in Asian performing arts. London/New York: Routledge Curzon.

Widodo, Dukut Imam et al. (eds). 2006. Malang tempo doeloe, djilid 2. Malang: Bayumedia Publishing.

William, Lea E. 1960. Overseas Chinese nationalism; The genesis of the Pan Chinese Movement in Indonesia, 1900-1916. Glencoe: The Free Press. 